\title{
PENERAPAN NILAI PANCASILA SILA KE-4 DALAM DINAMIKA KEHIDUPAN KULIAH ONLINE PADA MASA PANDEMI COVID-19
}

\author{
Aditya Anandita Dharma P., Dwiki Ananda Classirio, Sarah Hanifah, \& Viorella Angelica \\ Hadi Guntoro \\ Institut Teknologi Bandung \\ E-mail: aditsareski23@gmail.com
}

\begin{abstract}
Abstrak
Dinamika dalam mengaktualisasikan nilai Pancasila ke dalam kehidupan berbangsa, dan bernegara adalah suatu kewajiban agar Pancasila selalu relevan dalam fungsinya sebagai pedoman untuk pengambilan kebijaksanaan dan pemecahan masalah dalam kehidupan berbangsa dan bernegara. Pada masa pandemi COVID-19 ini, dibutuhkannya kerjasama dari berbagai pihak untuk terus dapat menurunkan nilai-nilai dinamika kehidupan berbangsa dan bernegara kepada generasi selanjutnya dengan baik. Makna dari adanya dinamika dalam aktualisasi nilai sila ke empat dari Pancasila pada kehidupan adalah selalu terjadinya perubahan dan pembaharuan dalam mentransformasikan nilai Pancasila ke dalam norma dan praktik hidup dengan menjaga konsistensi, relevansi, dan kontekstualisasi-nya. Sedangkan perubahan dan pembaharuan yang berkesinambungan terjadi apabila terdapat dinamika internal (self renewal) dan penyerapan terhadap nilai-nilai asing yang relevan untuk pengembangan dan pengayaan ideologi Pancasila. Salah satu kontribusi yang dapat dilakukan untuk mengaktualisasikan nilai tersebut adalah dengan mengajarkan Pancasila dan Pendidikan Kewarganegaraan. Data yang disajikan berasal dari kajian pustaka dan penelusuran literatur dari berbagai sumber yang relevan. Adapun metode yang dilakukan adalah dengan metode kualitatif. Hasil yang diperoleh berdasarkan temuan kajian pustaka dan penelusuran literatur menunjukkan bahwa di era globalisasi saat ini bahkan pandemi COVID-19, banyak masyarakat, generasi muda yang tidak mengindahkan bahkan mengetahui peranan penting Pancasila dan Kewarganegaraan di kehidupan berbangsa dan bernegara.
\end{abstract}

Kata Kunci: Pendidikan, Pandemi Covid-19, Kehidupan, Berbangsa, Bernegara.

\begin{abstract}
Dynamics in actualizing the value of Pancasila into the life of the nation, and state is an obligation that Pancasila is always relevant in its function as a guideline for wisdom taking and problem solving in the life of the nation and state. During the COVID-19 pandemic, cooperation from various parties is needed to continue to be able to reduce the dynamic values of national and state life to the next generation well. The meaning of the dynamics in the actualization of the fourth precept value of Pancasila in life is always a change and renewal in transforming the value of Pancasila into living norms and practices by maintaining consistency, relevance, and contextualization. While continuous change and renewal occur when there is an internal dynamic (self renewal) and absorption of foreign values relevant to the development and enrichment of Pancasila ideology. One of the contributions that can be made to actualize these values is to teach Pancasila and Citizenship Education. The data presented comes from literature studies and literature searches from a variety of relevant sources. The method is done by qualitative method. Results obtained based on the findings of literature studies and literature searches show that in the current era of globalization even the COVID-19 pandemic, many people, young people who do not heed even know the important role of Pancasila and Citizenship in the life of the nation and state.
\end{abstract}

Keywords: Education, Covid-19 Pandemic, Life, Nationhood, Statehood.

\section{PENDAHULUAN}

Di masa pandemi COVID-19 ini, pendidikan menjadi topik yang hangat di berbagai negara termasuk Indonesia. Hal ini dikarenakan semenjak merebaknya wabah COVID-19, pelaksanaan kegiatan belajar 
dan mengajar dialihkan menjadi kegiatan online yang mana dapat mempengaruhi proses pembelajaran. Hal ini didukung dengan data dari organisasi pendidikan, keilmuan, dan kebudayaan PBB (UNESCO), setidaknya ada 209.5 juta mahasiswa/i di seluruh dunia yang aktivitas belajarnya menjadi terganggu akibat sekolah yang ditutup.

Pendidikan juga sangat berperan penting dalam menurunkan nilai-nilai pancasila ke generasi selanjutnya (Nurgiansah, 2021b). Nilai-nilai Pancasila merupakan nilai-nilai yang menjadi landasan atau pandangan dalam kehidupan kita sehari-hari dimulai dari berkehidupan di masyarakat hingga mengambil suatu keputusan negara (Nurgiansah, 2020). Oleh karena itu, meskipun dalam masa pandemi nilai-nilai ini harus tetap ditegakkan terutama dalam melaksanakan kebijakan pemerintah dalam bidang Pendidikan.

Salah satu nilai Pancasila yang sangat penting untuk ditegakkan dan dilaksanakan oleh pelajar, namun mengalami kesulitan dalam penurunan nilainya terdapat pada nilai penanaman rasa demokrasi dan musyarah yang tercantum pada sila ke-4, yaitu Kerakyatan yang dipimpin oleh Hikmat Kebijaksanaan dalam Permusyawaratan/Perwakilan. Hal ini dikarenakan dengan adanya social distancing, dan juga kegiatan serba-online mengakibatkan pelajar menjadi lebih individualis dan sulit untuk melaksanakan sesuatu secara bersama-sama. Akibatnya, pengaplikasian dari nilai sila ke-4 ini menjadi menurun dibandingkan ketika proses belajar dan mengajar secara offline.

Oleh karena itu, dibutuhkannya penelitian tentang analisis metode terbaik dalam penerapan nilai Pancasila sila ke-4 dalam dinamika kehidupan sekolah online pada masa pandemi COVID-19. Kemudian, juga tentu saja dibutuhkannya kerja sama antara tenaga pendidik selaku guru di sekolah dan juga orang tua selaku guru di rumah untuk berkontribusi dalam penurunan kesadaran moral kepada anakanaknya sebagai calon generasi penerus bangsa agar dapat diterapkan dalam kehidupannya sehari-hari.

Berdasarkan latar belakang masalah yang diangkat, terdapat beberapa rumusan masalah yang muncul yaitu sebagai berikut: bagaimana kesadaran pelajar saat ini mengenai pentingnya menanamkan nilainilai pancasila dalam meningkatkan moral? mengapa penurunan kesadaran moral penting bagi generasi penerus bangsa? apa yang membuat terjadinya penurunan moral selama kegiatan sekolah online?

Adapun tujuan dari penelitian ini yang mengacu pada rumusan masalah di atas adalah untuk meningkatkan awareness tentang moral selama pandemi COVID-19, untuk memahami pentingnya penurunan kesadaran moral kepada generasi penerus bangsa, untuk memahami faktor yang menyebabkan penurunan kesadaran moral selama sekolah online, dan untuk memahami metode yang tepat dalam menerapkan nilai-nilai pancasila kepada pelajar di masa pandemi COVID-19.

Manfaat dari penelitian ini yaitu agar pembaca dapat mengetahui bagaimana kondisi penanaman nilai-nilai pancasila pada pelajar saat menjalani sekolah online dan juga metode apa yang tepat dalam penerapan nilai-nilai pancasila di masa pandemi COVID-19 ini.

\section{METODE PENELITIAN}

Metode penelitian yang digunakan pada penelitian ini adalah metode kualitatif. Metode kualitatif merupakan metode dengan mengambil data dan dijabarkan secara deksriptif dengan interpretasi yang tepat (Nurgiansah, 2018). Penelitian dengan metode ini akan menggambarkan dan menganalisis pengaruh dari penerapan nilai Pancasila sila ke empat dalam dinamika kehidupan sekolah online pada 
masa pandemi COVID-19 ini dengan menggunakkan interpretasi yang tepat.

Instrumen yang digunakan pada penelitian ini berupa angket dan catatan observasi. Angket yang berisi kuesioner ini dibuat dengan menggunakkan Google Form. Catatan observasi yang digunakan merupakan hasil dari berbagai jurnal yang sudah dilakukan pengecekan terhadap validitas dan reliabilitasnya. Data yang diperoleh pada angket dan catatan observasi digunakan untuk mengetahui pengaruh dan hubungan dari pentingnya kesadaran moral selama sekolah online dengan Pancasila sila ke empat. Perhitungan dari data yang telah diperoleh akan di analisis menggunakan persentase. Persentase data bertujuan untuk melihat perbandingan jawaban yang diberikan oleh setiap responden, karena frekuensi jawaban responden untuk setiap opsi tidak sama. Partisipan di penelitian ini berjumlah sekitar 40 orang dengan karakteristik sebagai mahasiwa/i yang mengikuti sekolah online dan dari berbagai macam daerah di Indonesia. Partisipan dipilih secara acak dengan asumsi akan mendapatkan data yang beragam mengenai pengaruh, hubungan, dan juga penerapan dari Pancasila sila ke empat tersebut.

Prosedur Penelitian terdiri dari beberapa prosedur yang dilakukan dalam penelitian ini, yang pertama tahap persiapan, pada tahap persiapan ini dilakukan langkah-langkah sebagai berikut: menyusun artikel ilmiah, konsultasi dengan dosen mengenai Artikel Ilmiah, menyusun instrumen penelitian berupa angket dan catatan observasi. Yang kedua adalah tahap pelaksanaan, pada tahap pelaksanaan ini dilakukan dengan cara melakukan observasi dan memberikan angket berupa tanya jawab kepada partisipan. Tahap ketiga yaitu tahap analisis, dan Evaluasi, pada tahap ini dilakukan langkah-langkah seperti mengumpulkan data, mengolah dan menganalisis data hasil penelitian menggunakan persentase, dan memperoleh kesimpulan.

\section{HASIL PENELITIAN DAN PEMBAHASAN Hasil Penelitian}

Berdasarkan penelitian yang telah dilakukan, diperoleh data bahwa mahasiswa/i telah menanamkan nilai-nilai Pancasila dalam meningkatkan moral sejak dini. Hanya saja, nilai-nilai moral tersebut tidak dapat dimanfaatkan secara maksimal karena adanya pembatasan aktivitas masyarakat sehingga terkesan mengalami stagnasi. Dengan adanya pelaksanaan kegiatan belajar dan mengajar dialihkan menjadi kegiatan online, membuat pelajar kurang berinteraksi secara langsung. Sebenarnya interaksi secara langsung tersebut merupakan sarana komunikasi terbaik untuk menerapkan nilai-nilai Pancasila bagi para pelajar. Adapun hasil temuan-temuan untuk menjawab tujuan penelitian yaitu sebagai berikut.

\section{Meningkatkan Awareness tentang Moral selama Pandemi COVID-19}

Berdasarkan temuan penelitian diperoleh data bahwa pembelajaran jarak jauh ini mengakibatkan lunturnya nilai moral dan karakter dalam diri mahasiswa/i akibat kurangnya interaksi langsung. Hal ini menyebabkan penurunan moral pada kebanyakan mahasiswa/i saat ini, terutama dalam hal mengemukakan pendapat saat berdiskusi secara online. Berbagai kasus yang ada menjadi fakta bahwa generasi saat ini tengah mengalami penurunan moral mahasiswa/i bangsa yang seharusnya menjadi generasi penerus bangsa (Nurgiansah, 2021a).

Untuk mengatasi problematika di atas, perlunya penguatan dan penanaman nilai-nilai yang dapat menumbuhkan sikap positif yang dapat menyelesaikan berbagai permasalahan yang ada. Pendidikan dan penanaman nilai-nilai pancasila sangatlah penting untuk diimplementasikan agar 
terbentuknya generasi yang mempunyai nilai moral dan karakter yang bermutu, sehingga generasi muda nanti mampu terjun ke lingkungan masyarakat dengan memiliki etika, moral, tata karma, sopan santun dalam menjalankan kehidupan berbangsa dan bernegara. Oleh karena itu, sangat perlu mengimplementasikan nilainilai pancasila pada mahasiswa/i di masa pandemi ini.

\section{Pemahaman Pentingnya Penurunan Kesadaran Moral kepada Generasi Penerus Bangsa}

Berdasarkan temuan penelitian diperoleh data fenomena dan kondisi ideal mahasiswa/i sebagai generasi penerus bangsa dimana pendidikan nilai moral perlu ditanamkan sejak usia dini dan harus dipantau secara serius, serta dilaksanakan dengan perencanaan yang matang dan program yang berkualitas, contohnya dengan jumlah jam program pembelajaran yang memadai dan jelas, teknik dan pendekatan proses pembelajaran handal, pemberian tugas yang berorientasi pada penanaman nilai-nilai pancasila serta fasilitas yang memadai. Apabila hal ini dapat dilaksanakan dengan baik, maka generasi penerus bangsa akan memiliki moral yang baik, hati mulia, budi pekerti yang luhur, empati, dan bertanggungjawab.

\section{Pemahaman Faktor yang Menyebabkan Penurunan Kesadaran Moral Selama Kuliah Online}

Berdasarkan temuan penelitian diperoleh data bahwa faktor utama penyebab penurunan moral pada mahasiswa/i adalah kurangnya interaksi secara langsung antarsesama. Dengan adanya pelaksanaan kegiatan belajar dan mengajar dialihkan menjadi kegiatan online, membuat mahasiswa/i kurang berinteraksi secara langsung dimana sebenarnya interaksi secara langsung tersebut merupakan sarana komunikasi terbaik untuk menanamkan dan menerapkan nilainilai Pancasila bagi para mahasiswa/i, apalagi ketika membahas penerapan nilai kemusyawaratan di antara mereka dalam mengkaji suatu permasalahan secara online. Akibatnya kebanyakan dari mahasiswa/i lebih memilih untuk menutup diri dan enggan memberikan pendapat ketika dalam suatu musyawarah. Didukung dengan adanya kemajuan teknologi terutama internet, kebanyakan dari mahasiswa/i lebih banyak menghabiskan waktu dalam dunia maya pada saat jam pembelajaran seperti bermain games dan media sosial.

Adapun faktor lain seperti lingkungan dan orang tua juga berpengaruh besar terhadap penurunan kesadaran moral selama kuliah online. Faktor orang tua sangat ditekankan disini karena apabila orang tua menjalankan tugas dan tanggung jawab dengan sebaik-baiknya dalam mendidik serta berinteraksi pada anakanaknya selama di rumah, maka permasalahan ini dapat diminimalisir. Sedangkan, apabila orang tua tidak menanamkan nilai-nilai pancasila pada anaknya seperti memberikan contoh yang kurang baik, kurangnya kasih sayang orang tua kepada anaknya, dan buruknya komunikasi antara orang tua kepada anak dianggap sebagai penyebab penurunan kesadaran moral terhadap nilai Pancasila dan membuat mahasiswa/i berkembang dengan kurang optimal dan bisa saja berujung pada hal-hal negatif.

Orang tua yang mengamalkan nilainilai agama dalam keluarga dan mengajarkan pada anaknya, kasih sayang dan waktu yang berkualitas bersama anakanaknya, keterlibatan seorang orang tua dalam mendidik anaknya, serta adanya komunikasi yang baik tentunya akan membuat pelajar mampu mengamalkan nilai Pancasila dalam kehidupannya seharihari dan menjadi pribadi yang lebih baik. 


\section{Penerapan Metode yang Tepat dalam Menerapkan Nilai-Nilai Pancasila kepada Pelajar di Masa Pandemi COVID- 19}

Berdasarkan amanat Perpres Nomor 87 Tahun 2017 tentang Penguatan Pendidikan Karakter, satuan pendidikan bertanggung jawab untuk memperkuat karakter peserta didik melalui harmonisasi olah hati, olah rasa, olah pikir, dan olah raga dengan pelibatan dan kerja sama antara satuan pendidikan, keluarga, dan masyarakat sebagai bagian dari Gerakan Nasional Revolusi Mental (GNRM).

Oleh karena itu, diperlukan metode yang tepat agar dapat menanamkan nilainilai karakter pancasila dalam diri peserta didik pada masa pandemi COVID-19. Salah satunya dengan cara mengimplementasikan nilai Pancasila sila ke empat dalam dinamika kehidupan kuliah online pada masa pandemi COVID-19. Adapun metode yang bisa diterapkan pelajar untuk menanamkan nilai Pancasila sila ke empat dalam dinamika kehidupan sekolah online pada masa pandemi COVID19 , antara lain sebagai berikut.

Metode yang digunakan adalah pendekatan kualitatif dengan sumber data berupa angket dan catatan observasi yang berisi kuesioner. Instrumen penelitian ini dibuat dengan menggunakkan Google Form dengan literatur lainnya yang diambil dari jurnal ataupun berita dan sudah dilakukan pengecekan terhadap validitas serta reliabilitasnya. Hasil dari penelitian ini adalah sebagian besar mahasiswa/i yang mengikuti kuliah online dari berbagai macam daerah di Indonesia beranggapan bahwa mereka mengalami penurunan kesadaran moral yang disebabkan karena tidak adanya interaksi langsung antar pelajar yang mempengaruhi perilaku mahasiswa/i sehingga memiliki kepribadian yang tertutup.

\section{Pelajar Bebas Mengungkapkan Pendapat dengan Berdiskusi Bersama}

Pemerintah telah menjamin setiap masyarakatnya mempunyai hak dan kebebasan untuk mengutarakan pendapatan dan menentukan keinginannya. Cara sederhana untuk menanamkan nilai sila keempat ini adalah dengan menanyakan dan memberi kebebasan pelajar untuk berpendapat. Contohnya dengan adanya tugas kelompok, pelajar dapat berdiskusi dan menyuarakan pendapatnya masing-masing. Adanya perkembangan internet yang menyediakan berbagai media komunikasi yang fleksibel membuat kegiatan interaksi secara tidak langsung seharusnya tetap dapat dilakukan baik meskipun dibatasi oleh layar. Secara tidak langsung penanaman nilai sila keempat yaitu memberikan wadah bagi pelajar untuk dapat menyuarakan dan menghargai keputusan orang lain dalam menyelesaikan permasalahan yang dibahas dapat terlaksana dengan baik. Dengan menerapkan hal tersebut, niscaya pelajar akan menjadi pribadi yang aktif, memiliki keinginan untuk berpendapat dan menghargai pendapat orang lain.

Kebebasan berpendapat juga merupakan bagian penting dari sebuah demokrasi, kebebasan ini memiliki dasar hukum yang telah diatur dalam pasal 28 UUD Negara Republik Indonesia 1945 yang menyatakan bahwa kebebasan bertanggung jawab dan bertindak untuk menyampaikan pendapat dimuka umum. Jadi demokrasi pun memiliki pilar yang mana berpendapat itu bebas namun dengan pendapat yang mampu dipertanggungjawabkan dengan didasarkan pada fakta yang ada, dan tanpa menyakiti satu sama lainnya dengan mengingat adanya HAM, karena hak setiap individu tentunya juga dibatasi oleh hak orang lain. 


\section{Pembahasan}

Berdasarkan hasil penelitian yang dilakukan melalui angket diberikan beberapa pertanyaan terkait topik kita teliti. Pertanyaan yang diberi dalam angket adalah sebagai berikut:

1. Menurut Anda, seberapa pentingnya penanaman moral terhadap penerus bangsa? (Pertanyaan dijawab dengan rating angka 1 sampai 10) disertai dengan alasan memilih jawaban tersebut.

2. Menurut Anda, apakah bersekolah online selama masa pandemi ini bisa menyebabkan penurunan kesadaran moral? disertai dengan alasan memilih jawaban tersebut.

3. Menurut Anda, apakah isi dari sila ke-4 diperlukan dalam menjalani sekolah online?

4. Apa keuntungan dari nilai sila tersebut bagi Anda?

5. Apakah Anda adalah orang yang mengamalkan nilai dari sila tersebut?

6. Menurut Anda, sejak kapan seharusnya penurunan dan pengamalan dari nilai sila tersebut dilaksanakan?

Hasil yang didapatkan dari keenam pertanyaan di atas yaitu sebagai berikut:

1. Pada pertanyaan pertama responden menjawab dengan skala angka dengan angka rata-rata yaitu sembilan. Hal ini menunjukkan bahwa penanaman moral terhadap penerus bangsa dianggap sebagai sesuatu yang penting bagi responden dengan alasan bahwa moral adalah suatu pondasi untuk kepribadian seseorang, suatu yang penting untuk kemajuan negara, dan moral adalah suatu hal yang lebih utama dari pendidikan.

2. Pada pertanyaan kedua responden mayoritas menjawab bahwa bersekolah online mungkin bisa menyebabkan penurunan kesadaran moral. Sebanyak $50 \%$ responden menyetujui bahwa sekolah online menyebabkan penurunan moral dengan hanya sebagian kecil orang yang menjawab tidak yaitu sekitar $5 \%$ dan sisanya menjawab mungkin. Alasan responden menjawab karena penurunan moral bisa terjadi tetapi tergantung dengan kesadaran murid tersebut sementara yang menjawab iya mengungkapkan bahwa murid menjadi sulit dikontrol dan menjadi tidak acuh selama pembelajaran online karena tidak bisa dikontrol secara langsung. Responden yang menjawab tidak mempunyai alasan bahwa kita dalam situasi yang baru dan tidak ada penurunan moral yang terjadi.

3. Pada pertanyaan ketiga mayoritas responden menjawab bahwa sila ke-4 penting dalam menjalani sekolah online sementara yang menjawab sila ke-4 mungkin penting dalam sekolah online hanya sembilan responden dan yang menjawab tidak penting hanya satu responden.

4. Pada pertanyaan keempat mayoritas responden menjawab dengan keuntungan sila ke-4 adalah permasalahan bisa dirundingkan dengan cara musyawarah yang adil dan tidak akan menimbulkan permusuhan kedepannya.

5. Pada pertanyaan kelima responden mayoritas menjawab bahwa mereka mengamalkan nilai dari sila ke-4 tersebut. Hampir semua responden menjawab bahwa mereka adalah orang yang mengamalkan sila ke-4.

6. Pada pertanyaan keenam mayoritas responden menjawab bahwa penurunan dan pengamalan nilai sila keempat dilaksanakan dari sejak dini, sejak SD, atau sejak TK dengan jawaban lain seperti sejak SMP. 


\section{Analisis dan Pembahasan Hasil Penelitian}

Berdasarkan analisis yang dilakukan terhadap data yang diperoleh, dapat disimpulkan bahwa masyarakat mempunyai kesadaran yang cukup tinggi terhadap pentingnya nilai moral di kehidupan ini. Hal ini tentu saja dapat dipengaruhi oleh lingkungan sekitar terutama di dunia akademik dan profesi. Pendidikan moral memang merupakan hal yang sangat penting dan tanpanya, tentu suatu bangsa bisa hancur. Pendidikan moral ini memang harus ditanamkan sejak dini dan juga harus dikelola dengan serius agar generasi penerus bangsa tidak justru merugikan bangsa. Generasi penerus bangsa harus bisa jadi contoh untuk generasi kedepannya sehingga suatu bangsa bisa terus berkembang dan mempunyai pondasi yang baik untuk masa depannya.

Pendidikan daring pada masa pandemi ini memang berpotensi menjadi faktor akan terjadinya penurunan nilai moral. Hal ini disebabkan kurangnya kontrol dan kesadaran pelajar ketika melakukan pelajaran secara daring. Pelajar menjadi tidak acuh dan merasa tidak ada yang memperhatikan mereka jika tidak mengikuti pembelajaran sebagaimana mestinya.

Sila keempat yang berbunyi "Kerakyatan yang Dipimpin Dalam Hikmat Kebijaksanaan dalam Permusyawaratan Perwakilan", mempunyai arti prinsip bermusyawarah dikedepankan untuk mufakat melalui wakil-wakilnya dan badanbadan perwakilan dalam memperjuangkan mandat rakyat. Salah satu makna Pancasila juga berkaitan erat dengan permusyawaratan. Permusyawaratan dalam sila keempat dimaknai sebagai pembuatan keputusan secara bulat, dengan dilakukan secara bersama melalui jalan kebijaksanaan. Secara keseluruhan makna sila keempat Pancasila ini adalah bahwa kekuasaan ada di tangan rakyat. Dalam melaksanakan kekuasaannya, rakyat menjalankan sistem perwakilan, dan keputusan-keputusan yang diambil dilakukan dengan musyawarah, yang dikendalikan dengan pikiran yang sehat, logis, serta penuh tanggung jawab baik kepada Tuhan maupun rakyat yang diwakilinya.

Dari hasil angket didapatkan bahwa mayoritas responden menganggap sila keempat Pancasila mempunyai peran yang penting dalam pendidikan daring pada saat masa pandemi ini. Mereka berpendapat bahwa nilai musyawarah dalam sila tersebut dimana keputusan diambil secara bulat secara bersama-sama dengan bijaksana mempunyai nilai yang penting bagi kehidupan akademik mereka. Mereka menganggap sila keempat merupakan hal yang penting karena keadilan menurut mereka adalah hal yang sangat krusial begitu juga dengan penyelesaian masalah yang adil dan bijaksana. Dari segi keorganisasian, musyawarah akan menjadi salah satu metode dalam memutuskan suatu solusi dimana musyawarah akan menghasilkan suatu keputusan yang bulat.

Dari hasil angket, responden juga berpendapat bahwa pengamalan nilai sila keempat ini harus dilakukan sejak dini sebagaimana halnya dengan nilai moral. Tentunya pendidikan sejak dini memang menjadi salah satu cara untuk membuat kebiasaaan yang paling umum. Sama halnya dengan kebiasaaan sehari-hari, nilai yang terkandung pada sila keempat ini tentunya agar menjadi suatu nilai yang melekat pada seseorang secara terus menerus diperlukan pendidikan sejak dini.

\section{KESIMPULAN}

Berdasarkan penelitian yang dilakukan, didapatkan seberapa kesadaran masyarakat akan moral terutama pada generasi penerus bangsa bahwasannya masyarakat mempunyai kesadaran yang 
cukup tinggi terhadap pentingnya moral pada generasi penerus bangsa sehingga dapat disimpulkan bahwa masyarakat tidak berpikir bahwa akademik saja yang penting melainkan gabungan antara akademik dan moral seseorang yang akan membuat generasi penerus bangsa yang berkualitas sekaligus menunjukkan bahwa dengan pandemi COVID-19 ini masyarakat tidak mengalami penurunan terhadap pentingnya penerapan nilai moral dalam kehidupan.

Tidak hanya itu, dari hasil penelitian ini juga didapatkan bahwa masyarakat juga mempunyai kesadaran dalam mengamalkan sila keempat Pancasila di kehidupan mereka. Pentingnya nilai sila keempat dalam pendidikan daring, dan pengamalan nilai-nilai tersebut sejak dini. Hal ini menunjukan bahwa kesadaran masyarakat dalam mengamalkan nilai Pancasila masih bisa dianggap memadai walaupun saat ini negara kita masih dilanda oleh pandemi Covid-19. Namun, tentunya hal ini perlu didukung dengan adanya metode pembelajaran online yang baik seperti, diadakannya kegiatan diskusi bersama yang sehat saat kelas sehingga dapat membangkitkan semangat mahasiswa/i untuk berpendapat tanpa merasa takut karena salah.

Pembelajaran online mengakibatkan kurangnya interaksi serta komunikasi secara langsung antar mahasiswa maupun antara mahasiswa dengan dosen sehingga rentan terjadinya miskomunikasi. Berkenaan dengan penerapan nilai-nilai Pancasila, kondisi di atas terkait dengan sila keempat, yaitu Kerakyatan Yang Dipimpin Oleh Hikmat Kebijaksanaan dalam Permusyawaratan/Perwakilan. Interaksi sosial secara langsung dapat membuat kegiatan diskusi dan pencarian solusi dengan cara musyawarah di antara mahasiswa dapat lebih mudah dilaksanakan. Mahasiswa diharapkan dalam keadaan pandemi seperti ini tidak menjadi pribadi yang individual dan rasa nasionalisme tetap ada dalam diri mahasiswa.

\section{DAFTAR PUSTAKA}

Ahmad, R. (2006). Strategi Penanaman Nilai-Nilai Pendidikan Islam Pada Peserta Didik. PT Sinar Grafika.

Anugrahana, A. (n.d.). Hambatan, Solusi Dan Harapan: Pembelajaran Daring Selama Masa Pandemi Covid-19 Oleh Guru Sekolah Dasar. PGSD Universitas Sanata Dharma.

Azhar. (n.d.). Penerapan Nilai-Nilai Moral dan Karakter Dalam PPKn Di Smp Darul Hikmah Mataram. Civicus Dan Pendidikan Pancasila Dan Kewarganegaraan, 6(1).

Bahri, S. (n.d.). Implementasi Pendidikan Karakter Dalam Mengatasi Krisis Moral Di Sekolah. Ta'allum, 3(1).

Cara Mudah Menanamkan Nilai-nilai Pancasila Pada Anak Sejak Kecil. (n.d.). BPIP. Retrieved November 20, 2021, from https://bpip.go.id/bpip/berita/1035/342/cara-mudahmenanamkan-nilai-nilai-pancasila-pada-anak-sejak-kecil.html

Eddy, I. W. T. (2018). AKTUALISASI NILAI PANCASILA DALAM KEHIDUPAN BERBANGSA DAN BERNEGARA. DHARMASMRTI, 1(18), 116.

Fatiha, N. (n.d.). Kemerosotan Moral Siswa Pada Masa Pandemic Covid 19: Meneropong Eksistensi Guru Pendidikan Agama Islam. Jurnal Pendidikan Agama Islam, 1, 2.

Handitya, B. (2019). Menyemai Nilai Pancasila Pada Generasi Muda Cendekia. DIL Indonesia Jurnal, 2(1).

Isnaini, P. N., \& Dewi, D. A. (2021). UPAYA MENERAPKAN NILAI-NILAI PANCASILA DI MASA PANDEMI COVID-19. Jurnal Kewarganegaraan, 5(2). 
Jahroh, W. S., \& Sutarna, N. (2020). Pendidikan Karakter Sebagai Upaya Mengatasi Degradasi Moral. Prosiding Seminar Nasional Inovasi Pendidikan.

Kumparan SAINS. (2020, March 25). Imbas Pandemi Virus Corona Bagi Dunia Pendidikan Indonesia dan Global. Kumparan. Retrieved November 11, 2021, from https://kumparan.com/kumparansains/imbaspandemi-virus-corona-bagi-duniapendidikanindonesia-dan-global-1t5YVXRYAbo/full

Langkah Mudah Menanamkan Nilai-nilai Pancasila Sejak Usia Sekolah. (2021, March 15). BPK Penabur. $\quad$ Retrieved November 19, 2021, from https://bpkpenabur.or.id/news/blog/langkah-mudah-menanamkan-nilai-nilaipancasila-sejak-usia-sekolah

Maftuh, B. (2008). Internalisasi Nilai-Nilai Pancasila Dan Nasionalisme Melalui Pendidikan Kewarganegaraan. Jurnal Educationist, 2(2).

Murdiano, M. (2008). Metode Penanaman Nilai Moral Untuk Anak Usia Dini. Jurnal Kependidikan, 38(2).

Naiborhu, M., SIburian, L., \& Hulu, Y. (2020). Hubungan Pemahaman Sila Ke Empat Pancasila Dengan Sikap Demokratis Masyarakat Desa Laenuaha. Jurnal Pendidikan Pancasila dan Kewarganegaraan, 2(2).

Nawawi, A. (2018). Pentingnya Pendidikan Nilai Moral Bagi Generasi Penerus. INSANIA Jurnal Pemikiran Alternatif Kependidikan, 16(2).

Nurgiansah, T. H. (2018). Pengembangan Kesadaran Hukum Berlalu Lintas Siswa Melalui Model Pembelajaran Jurisprudensial Dalam Pendidikan Kewarganegaraan (Studi Kasus di SMK Bina Essa Kabupaten Bandung Barat Kelas X Administrasi Perkantoran). Tesis. Repository Universitas Pendidikan Indonesia, Oktober. http://ieeeauthorcenter.ieee.org/wpcontent/uploads/IEEE-Reference-

Guide.pdf\%0Ahttp://wwwlib.murdoch.edu.au/find/citation/ieee.html\%0Ahttps://doi.or g/10.1016/j.cie.2019.07.022\%0Ahttps://github.com/ethereum/wiki/wiki/White-

Paper\%0Ahttps://tore.tuhh.de/hand

Nurgiansah, T. H. (2020). Filsafat Pendidikan. In Banyumas: CV Pena Persada.

Nurgiansah, T. H. (2021a). Pemanfaatan E-Learning Dalam Pembelajaran Pendidikan Kewarganegaraan. JINTECH: Journal of Information Technology, 2(2), 138-146.

Nurgiansah, T. H. (2021b). Pendidikan Pancasila. In Solok: CV Mitra Cendekia Media.

Nurizka, R. (2020). Internalisasi Nilai-Nilai Pancasila Dalam Membentuk Karakter Siswa Melalui Budaya Sekolah. 7(1).

Nurohmah, A. N., \& Dewi, D. A. (2021). Penanaman Nilai Moral dan Karakter di Era Pandemi melalui Pendidikan dengan Mengimplementasikan Nilai-Nilai Pancasila. Journal of Education, Psychology and Counseling, 3(1).

Pandemi, Pembelajaran Digital dan Ancaman Moralitas. (2020, September 2). AJNN. Retrieved November 19, 2021, from https://www.ajnn.net/news/pandemi-pembelajaran-digitaldan-ancaman-moralitas/index.html

Putra, A. S. (2020). Paradigma Belajar Mengaji Secara Online Pada Masa Pandemic Coronavirus Disease 2019 (Covid-19). Mataazir: Jurnal Administrasi Dan Manajemen Pendidikan, $1(1)$.

Rachma, H. (2013). Nilai-Nilai Dalam Pendidikan Karakter Bangsa Yang Berdasarkan Pancasila Dan UUD 1945. E-Journal Widya Non-Eksakta, 1(1).

Ratu, D. (2020). Pendidikan Dalam Masa Pandemi Covid-19. Jurnal Sinestesia, 10(1).

Setiawan, A. R., \& Mufassaroh, A. Z. (2020). Lembar Kegiatan Siswa untuk Pembelajaran Jarak Jauh Berdasarkan Literasi Saintifik pada Topik Penyakit Coronavirus 2019 (Covid-19). 
Sihombing, R. A., \& Lukitoyo, P. S. (2021). PERANAN PENTING PANCASILA DAN PENDIDIKAN KEWARGANEGARAAN SEBAGAI PENDIDIKAN KARAKTER DI MASA PANDEMI COVID19. Jurnal Pendidikan Kewarganegaraan Undiksha, 9(1), 49.

Yoga, I. P. (2020). Pendidikan Karakter Di Lingkungan Keluarga Selama Pembelajaran Jarak Jauh Pada Masa Pandemi Covid-19. Jurnal Ilmu Pendidikan, 3(2).

Yuni, E. (2019). Menumbuhkan Kesadaran Nasionalisme Generasi Muda Di Era Globalisasi Melalui Penerapan Nilai-Nilai Pancasila. Adil Jurnal Indonesia, 1(1).

Yusdiyanto. (2016). Makna Filosofis Nilai-Nilai Sila Ke-Empat Pancasila dalam Sistem Demokrasi di Indonesia. Fiat Justisia Journal of Law, 10(2). 